Kirsten Wølch Rasmussen \& Jan Engberg*

\title{
Genre Analysis of Legal Discourse
}

\section{Introduction}

In legal discourse, there are many different kinds of texts, written as well as oral. However, some of these texts present a number of similarities, and it is the study of these similarities which is the object of genre analysis.

There are many different views on the question of what the concept of genre covers, and there are important differences as to the criteria used for the determination of genres: text-external criteria (for example function, communicative purpose) or text-internal criteria (for example syntactic characteristics) or both text-external and -internal criteria. Because of the limited space of this paper, we will not go into this discussion, but instead present an analysis carried out according to one specific way of looking at genres, namely the model proposed by Bhatia (1993). ${ }^{1}$

\section{A model for genre analysis}

Bhatia, who has been particularly interested in genres within the legal discourse, defines genre in accordance with Swales (1990) as:

"a recognizable communicative event characterized by a set of communicative purpose(s) identified and mutually understood by the members of the professional or academic community in which it regularly occurs. Most often it is highly structured and conventionalized with constraints on allowable contributions in terms of their intent, positioning, form and functional value. These constraints, however, are often exploited by the expert members of the discourse community to achieve private intentions within the framework of socially recognized purpose(s). "(Bhatia 1993, 13).

1 For a detailed discussion of the concept of genre, see Bhatia 1996 and Bathia / Engberg / Frandsen / Johansen / Nielsen 1997.

* Kirsten Wølch Rasmussen

Fransk Institut

Handelshøjskolen $i$ Århus

Fuglesangs Allé 4

DK-8210 Århus V
* Jan Engberg Tysk Institut Handelshøjskolen $i$ Århus Fuglesangs Allé 4 DK-8210 Århus $V$ 
Bhatia thus views each genre as a part of a communicative process and analyses texts at three levels: the communicative purpose of the genre, its move-structure and the rhetorical strategies used.

The most important criterion for the determination and distinction of genres is the communicative purpose of the texts. The communicative purpose shapes and is reflected in the move-structure of the genre. The move-structure consists of a number of moves, i.e. partial actions, which are typically used by the members of a discourse community in order to accomplish the communicative purpose of the genre. These partial actions are in principle discriminative: they depend upon the communicative purpose of the genre. Therefore, major changes in the communicative purpose are likely to cause a change of partial actions, and changes in partial actions will bring about a change in the communicative purpose - and thus a change of genre. However, the movestructure is flexible to a certain extent, in the sense that certain moves may be facultative, whereas others are obligatory.

In his book, Bhatia distinguishes between two types of move-structures: the linear move-structure and the interactive move-structure.

For example, a judgement consists of a linear four-move-structure: 1) identifying the case, 2) establishing facts of the case, 3) arguing the case, and 4) pronouncing judgement (Bhatia 1993, 135-36). Legislative provisions consist of a two-part interactive structure comprising on the one hand the main provisionary clause and on the other hand the qualifications inserted within the structure of the sentence. "This structure is interactive in the sense that the move qualification typically interacts with several aspects of the move provisionary clause" (Bhatia 1993, 117).

Each move is verbalised by applying different rhetorical strategies, i.e. strategies used by the writer to accomplish a particular communicative intention at the level of the move, to formulate the partial action, so to speak. This could for example be the use of a particular organization of the text, use of a particular vocabulary or use of particular grammatical constructions (third person, present tense, nominalization, passive voice etc.). Unlike the moves, these rhetorical strategies are not discriminative, i.e. they can vary without changing the purpose (and thus 
the genre). To illustrate the theory, we shall in the following apply it in practice on a EC directive ${ }^{2}$.

\section{Analysis of the EC directive}

\subsection{Context - sender/receiver, their relationship and the extra-textual reality}

In order to define the communicative purpose of a text (the directive), it is necessary to analyse the situational context. In this paper, we shall concentrate upon the sender/receiver, their relationship and the extratextual reality.

There are various senders of the text: the Commission, which has proposed the text, the Council and the Parliament which are responsible for the adoption of the final text, and the legal draftsmen, who have actually written the text. The Council and the Parliament have a special status in relation to the other senders, because they are the law-making bodies. They could thus be classified as direct senders, whereas those who have only participated in the elaboration of the text, are indirect senders.

With regard to the receiver we can similarly distinguish between direct receivers (the competent national authorities of the member states, who are responsible for implementing the directive in the national legislation) and indirect receivers (the Court of Justice which has to see that the directive is implemented and observed by the member states, the draftsmen who write the national laws implementing the directive, the national courts, which have to take the directive into consideration, and the citizens of the member states).

The relationship between the direct sender and receiver is a relation of authority where the sender has a right to decide on behalf of the receiver. The Council and the Parliament, who are in a superior situation, lay down the law, and the member states have to obey the law.

The legal provisions create a world of obligations and rights: it is a future world and it is impossible to predict exactly what will happen within it. Unlike the sender in another typical legal communicative situ-

2 Directive 95/46/EC of the European Parliament and of the Council of 24 October 1995 on the protection of individuals with regard to the processing of personal data and on the free movement of such data (in French and in German). 
ation, the judge, who solves actual problems presented to him, the legislator gives solutions to hypothetical problems. In other words, he has to anticipate the situations that might arise in the future world.

\subsection{Communicative purpose}

On the basis of the analysis of the situational context, we are now able to define the communicative purpose of the directive:

The communicative purpose of the directive is to direct the (future) actions of the receivers (the member states) and thus regulate life in society.

\subsection{Move- and step-structures}

The next step of the genre analysis of the directive is to see how the communicative purpose is reflected in the move-structure. The purpose of the analysis is to determine the partial actions used for accomplishing the communicative purpose. Bhatia does not distinguish between different levels of the move-structure. But as it seems clear that all moves are not at the same level, we shall distinguish between moves at two levels: Moves at macro-level, i.e. moves at the level of the text as a whole, and moves at micro-level, i.e. at the level of the macro moves. In this paper, we shall call moves at micro-level steps, whereas the term moves is always used to denote moves at macro-level.

\subsubsection{Move-structure (macro-level)}

At the macro-level, we find a structure consisting of three moves (cf. table 1):

Move 1: Enactment

Move 2: Justification

Move 3: Establishing of rules

Move 1 enacts the directive. This is done by the so-called enactment or promulgation formula. This formula, which is divided into two distinct parts, contains the performative verb (arrêter), which marks the following text (move 3 ) as a speech act with the illocutionary force of enacting. The presence of this formula is a necessary condition for laying down the law. 
Move 2 gives the justification for the collection of rules in move 3 . This is done by referring to relevant texts, indicating the procedure followed and finally by stating the motives. The move consists of participial phrases - either in the past or the present tense - functioning as adverbials oriented towards the subject (Le Parlement europeen et le Conseil de l'Union européenne) in the promulgation formula.

Move 3 establishes the rules which are enacted, the legal provisions. These rules are represented in a succession of chapters, sections, articles and paragraphs, the basic principle being that each article reflects one conceptual unit in the form of a single sentence.

This move-structure is an example of a linear move-structure, as each of the moves ends, before the next move starts (although move 1 is divided into two separate parts). Furthermore, one move is the prerequisite of the following move, so the moves are not interactive.

Table 1: Move-structure of the directive (macro-level):

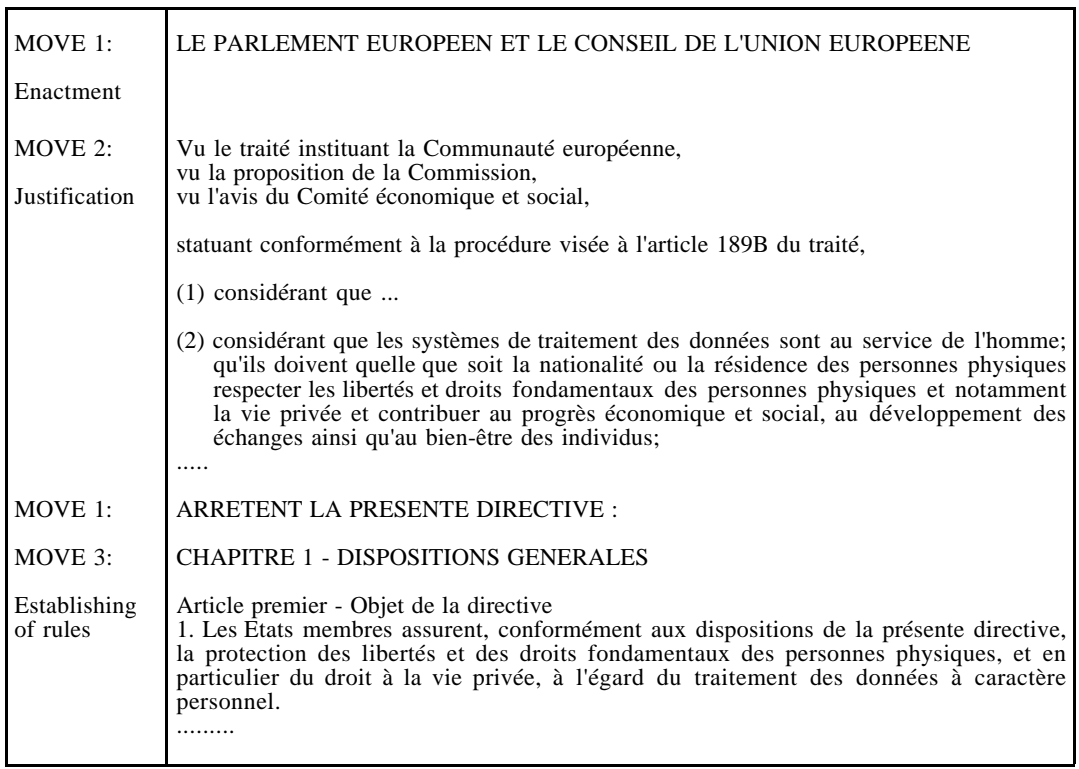

Each of the moves at the macro-level may consist of a number of steps, respectively. As the purpose of this paper is to concentrate on method- 
ological issues, we shall limit ourselves to looking more closely at move 3 , concentrating upon the interactive step-structure of this move.

\subsubsection{Step-structure of move 3 (micro-level)}

As mentioned, Bhatia has pointed out that legislative provisions consist of a two-part interactive structure of partial actions consisting on the one hand of what he calls the main provisionary clause (stating the legal consequences) and on the other hand the qualifications (stating required features of possible cases and conditions) inserted within the structure of the sentence (Bhatia 1993, 33). As we have here a structure below the level of the move, in accordance with Swales 1990 we prefer to talk here about these partial actions as steps. The step-structure is interactive in the sense that the step qualification interacts with several aspects of the step provisionary clause. Each one is meant to clarify various aspects of the legal provision.

We very clearly find this structure in the directive. The following section will investigate the structure of these steps within move 3 . As an example please note the following sentence from article 13 of the directive:

Sous réserve de garanties légales appropriées, excluant notamment que les données puissent être utilisées aux fins de mesures ou de décisions se rapportant à des personnes précises, les Etats membres peuvent, dans le cas où il n'existe manifestement aucun risque d'atteinte à la vie privée de la personne concernée, limiter par une mesure législative les droits prévus à l'article 12 lorsque les données sont traitées exclusivement aux fins de la recherche scientifique ou sont stockées sous la forme de données à caractère personnel pendant une durée n'excédant pas celle nécessaire à la seule finalité d'établissement de statistiques. (Art. 13, 2)

The structure of this sentence could be presented as follows: 
Table 2: Step-structure in move 3 (micro-level):

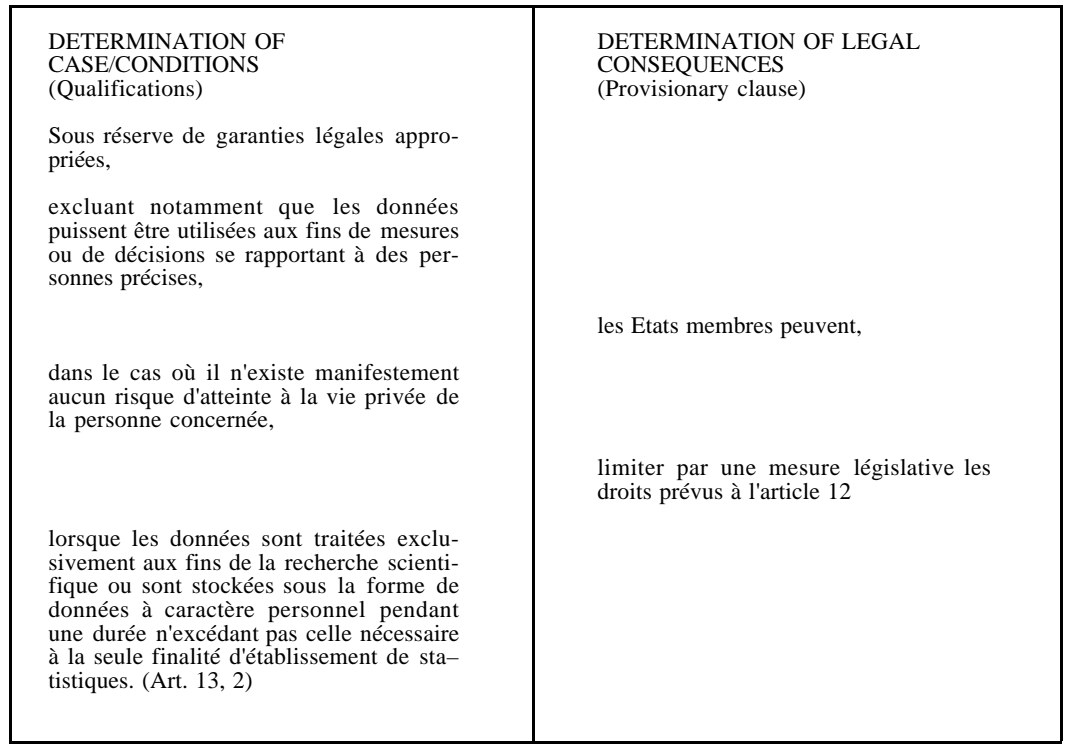

We see here that the structure of the legal provision is such that the provisionary clause is expressed in the main clause, whereas the tokens of the step qualifications are formulated as adverbials (adverbial clauses, prepositional and participial phrases). The qualifications are by far the most important part of the legal provisions, considering the amount of linguistic material and the thematic importance.

The above are examples of moves and steps found in the directive. All of these are in fact obligatory: They have to be there in order to enact the directive (cf. Art. 190 of the EC Treaty). Thus, they are defining features of texts of this genre, and must be characterized as moves according to Bhatia's definitions cited above. In the following section, we will have a closer look at the phrasing of these moves and steps, and thus proceed to the investigation of the rhetorical strategies used in the directive.

\subsection{Rhetorical strategies of move 3 (Establishing of rules)}

Investigating rhetorical strategies of texts as tokens of a genre is equivalent to giving descriptions of the use of linguistic material from the 
point of view of the moves and steps, i.e. from the point of view of the communicative purpose. So in this section we shall examine the relations between on the one hand the communicative purpose defined on the basis of the text-external analysis (sections 3.1-3.2), reflected in the structure of moves and steps, and on the other hand the linguistic material applied in the text.

On the basis of the text-external analyses carried out earlier in this paper we have put up as a hypothesis that the communicative purpose of the directive is to direct the future actions of the member states. In order to verify this hypothesis, we must now look at the characteristic rhetorical strategies used in the text and see to what extent they are in correspondence with the postulated communicative purpose. If we find correspondences, this may be seen as support for the hypothesis about the communicative purpose.

The following list is a non-exhaustive table of characteristic rhetorical strategies that might be investigated more thoroughly:

- Organization of the text (text parts

- Long and complex sentences

- Nominalizations

- Complex nominal phrases (many modifiers)

- Parallel structures

- Binominal (and multinominal) expressions

- Adverbial insertions

- Passive voice

The limited space of this paper does not allow us to treat all these rhetorical strategies in detail. Therefore, we have chosen to concentrate on one feature, namely the passive voice. The study of this feature is first carried out upon the French text, investigating whether the characteristics of the passive voice makes it suitable for realizing the communicative purpose. This first part of the analysis shows the explanatory aspect of genre analysis, connecting text-internal and text-external descriptions and thus giving so-called thick descriptions (Bhatia 1993, 5; 1012). After that, a contrastive study of the distribution of the passive voice within the steps of move 3 in the German and the French version of the directive is carried out, in order to find out whether there are differences between the way the passive voice is used in the same type of 
steps in texts of two different languages. This second part of the study focuses on the possibilities of genre analysis for cross-cultural studies.

\subsubsection{Passive voice as a rhetorical strategy in the move "Establishing of rules"}

By the term passive (i.e. the grammatical passive) is meant a construction with être + past participle, which is in a transformational relationship with an active construction, and which is characterized by the suppression of the subject of the active counterpart. The subject of the active counterpart is either expressed in the form of a prepositional phrase or deleted, whereas a possible object in the active construction becomes the subject of the passive, as exemplified in Le Conseil vote la directive - La directive est votée (par le Conseil). The passive with être + past participle, e.g. La directive est votée can either express the present action (= Le Conseil/On vote la directive) or the present result of a past action (= Le Conseil/On a voté la directive). In the following the term passive includes both types of passives.

\subsubsection{Frequency and types of passives}

Move $3^{3}$ contains 229 finite verb phrases. 76 (33\%) of these are passive verb phrases. Of the 229 finite verb phrases, 184 are non modal, whereas 45 include a modal auxiliary (pouvoir or devoir). 57 (31\%) of the non modal finite verb phrases and $19(42 \%)$ of the modal finite verb phrases are passives ${ }^{4}$. Of the 76 finite passive verb phrases, only 11 (14\%) passives are agentful (containing a prepositional phrase expressing the agent), whereas $65(86 \%)$ are agentless, the agentless passives thus being by far the most frequent. Furthermore, all passives in move 3 are constructed by direct transitive verbs, and they are all realized as personal passives (as for example in: Les moyens de traitement sont déterminés par des dispositions législatives).

\subsubsection{Functions of passives}

There are two types of factors explaining the use of the passive in move 3: functional and structural. The functional factors are: the omission of

3 In the following, the analyses of move 3 are based on Art. 1-24 of the directive.

4 The modal finite verb phrases are passives in so far as they consist of a finite modal verb and a passive infinitive. 
the agent, the promotion of the object of the corresponding active construction to subject-position, and thus to the typical theme-position, the focalizing of the agent or of the verb. The structural factors are: the organization of the complex sentence and the placement of the more weighty nominal phrases in final position. As it can be seen from the following examples, several of these factors not only often co-occur, they also interact.

\section{a) Omission of the agent}

As already mentioned, the agent is deleted in $86 \%$ of the passives. In the vast majority of these cases, the reference of the agent is indefinite (any person who/whoever performs the action etc. in question). The actual actor is unimportant, as in (1):

(1) Les Etats membres prévoient que les données à caractère personnel doivent être :(...) adéquates, pertinentes et non excessives au regard des finalités pour lesquelles elles sont collectées ou pour lesquelles elles sont traitées ultérieurement;

In a few cases the deleted agent represents the senders, i.e. the lawmaking bodies, or the directive (and thus indirectly the senders):

(2) les autorités qui sont susceptibles de recevoir communication de données dans le cadre d'une mission d'enquête particulière ne sont toutefois pas considérées comme des destinataires.

This means that in $86 \%$ of the passives the omission of the agent plays a part. However, these passives may also be motivated by other competing factors, such as for example the selection of theme.

\section{b) Theme-selection}

The passives in move 3, which are all characterized by the promotion of the object of the corresponding active construction, are often used to place Given information (elements which convey something that is known, or may be inferred, from the linguistic or from the situational context, cf. for instance Prince 1981) in subject-position, i.e. the unmarked theme-position, ${ }^{5}$ as in (3):

3) d) "responsable du traitement", la personne physique ou morale, l'autorité publique, le service ou tout autre organisme qui seul ou conjointement avec d'autres, détermine les finalités et les moyens du traitement de données à caractère personnel; lorsque les finalités et les

5 For an analysis of the French passive with regard to the information structure of the sentence in another legal genre, the contract, see Rasmussen 1996. 
moyens du traitement sont déterminées par des dispositions législatives ou réglementaires nationales ou communautaires ...

The agent of the passive (des dispositions législatives...), which would be realized as subject in the active counterpart, represents New information, as indicated by the indefinite article, and is therefore unsuitable as theme.

As shown in (4) the passive represents an excellent device for creating thematic cohesion and for structuring the text. In (4) the use of the passives (doivent être traitées, sont collectées etc.) of which some are coordinated with predicate constructions (doivent être adéquates etc.) thus allows the writer to maintain (les données à caractère personnel), repeated by the coreferential personal pronoun (elles), as the theme of a series of coordinated/subordinated clauses regardless of the syntactical level:

(4) Les Etats membres prévoient que les données à caractère personnel doivent être:

a) traitées loyalement et licitement;

b) collectées pour des finalités déterminées, explicites et légitimes, et ne pas être traitées ultérieurement de manière incompatible avec ces finalités. (...)

c) adéquates, pertinentes et non excessives au regard des finalités pour lesquelles elles sont collectées ou pour lesquelles elles sont traitées ultérieurement;

d) exactes et, si nécessaire, mises à jour; ...

e) conservées sous une forme permettant l'identification des personnes concernées ...

\section{c) Focus placement}

Simultaneously, the passive may be used to put end-focus ${ }^{6}$ on either the agent, which would be realized as subject of the corresponding active construction, or on the verb, which would appear early in the active counterpart, when one of these elements is considered to carry the largest amount of New information and therefore requires emphasis.

In (5) the agentful passive thus focalizes the agent, which represents the New information, by placing it in final position:

(5) Le registre peut être consulté par toute personne.

6 For a detailed discussion of the concept of focalization, see Nølke 1995. 
and in (6) the use of the agentless passive makes it possible to put endfocus on the verb:

(6) Les Etats membres prévoient que le responsable du traitement ou son représentant doit fournir à la personne auprès de laquelle il collecte des données la concernant, au moins les informations énumérées cidessous, sauf si la personne en est déjà informée:

\section{d) Organization of the complexe sentence}

The passive can also facilitate and simplify the syntactical organization of the complex sentence, because it may allow the writer to avoid a change of subject throughout the sentence or at least in several clauses, both in the case of coordination (7) and in the case of subordination (8).

In (7) the use of the passive furthermore allows the writer to avoid repeating the coreferential subject of the second passive construction (une telle décision), whereas in object-position in the corresponding active it would be necessary to repeat (une telle décision) at least by means of a personal pronoun:

(7) Les Etats membres prévoient, sous réserve des autres dispositions de la présente directive, qu'une personne peut être soumise à une décision telle que celle visée au paragraphe 1 si une telle décision :

a) est prise dans le cadre de la conclusion ou de l'exécution d'un contrat, à condition que la demande de conclusion ou d'exécution du contrat, introduite par la personne concernée, ait été satisfaite ...

b) est autorisée par une loi qui précise les mesures garantissant la sauvegarde. (Art 15, 2))

In (8) the use of the passive in the relative clause furthermore makes it possible to avoid the intrusive effect of an additional (non-coreferential) subject, which would be necessary in the active:

(8) ... lorsque le responsable du traitement désigne, conformément au droit national auquel il est soumis, un détaché à la protection des données à caractère personnel ..

In all of these cases, the general tendency to place the Given elements in subject-position evidently also favours the choice of the passive, because when two or more clauses have an element in common, this element is Given in the second clause etc.

\section{e) Placement of weighty nominal phrases in final position}

The passive is also used to put weighty, i.e. long and/or syntactically complex, nominal phrases at the end of the clause. In (9) the subject 
thus only contains 5 words, whereas the agent(s) contain(s) 43 words. Furthermore, the agents in (8), which are both coordinated and postqualified by past participle constructions, have a more complex inner structure than the subject.
Le paragraphe 1 ne s'applique pas lorsque le traitement des données est nécessaire aux fins de la médicine préventive, des diagnostics médicaux, de l'administration de soins ou de traitements ou de la ges- tion de services de santé et que le traitement de ces données est effec- tué par un praticien de la santé soumis à l'obligation du secret pro- fessionnel sanctionné par le droit national, ou par des réglementa- tions arrêtées par les autorités nationales compétentes au secret pro- fessionnel, ou par une autre personne également soumise à une obli- gation de secret équivalente.

By using the passive the writer avoids placing the more weighty nominal phrase as subject. He thus reduces the distance between the head of the nominal phrase functioning as subject and obtains a clause which is supposedly clearer and easier to understand than the corresponding active clause. It should, however, be noted that a weighty nominal phrase frequently represents a New element (the "weight" is often caused by the need to specify such an element). The passive may therefore also be used in these cases in order to focalize the New element expressed by the nominal phrase.

\subsubsection{Use of passive to realize the move "Establishing of rules"}

Having analysed the main functions of the passive voice in move 3 , it remains to see how these functions can help the sender to realize the communicative intention at the level of the move, which was to establish rules for the future actions of the receivers, and thus indirectly the communicative purpose of the directive as a whole.

As we have seen, the relationship between the sender and the receiver is one of authority: in move 3 the legislator prohibits and permits, and the member states have to obey the rules laid down. In this context, the sender may use the agentless passive in order to avoid overtly exposing his authority, to lessen the impact of the imposition on the receiver. The use of the agentless passive thus serves as a politeness strategy. Furthermore, the directive regulates not only the future behaviour of the law-making bodies of the member states, but indirectly 
also the behaviour of the citizens of these states. As the rules laid down are meant to apply to all citizens in the situations described, the actors of the (future) verbal actions etc. are indefinite. The use of the agentless passive makes it possible to avoid mentioning these actors and thus make the text impersonal and applicable to everybody.

We have also seen that the law-making bodies have to anticipate all eventualities in the future world created by the legal provisions. In other words the text has to be all-inclusive. As a result of this requirement combined with a general tendency to place one conceptual unit in a single sentence (cf. Cornu 1990, 291-304), legal provisions are characterized by long and complex sentences and nominal phrases, adverbial insertions at various positions in the sentences etc., cf. 3.4. In this linguistic context, the passive may be used:

- to place a Given element in subject-position, and thus ensure thematic cohesion

- to put end-focus on either the verb or the agent and thereby draw the attention of the receiver to these elements, when they are considered to carry the largest amount of new information

- to facilitate the connexion between clauses within the complexe sentences by maintaining the same subject, and finally,

- to place the more weighty nominal phrase as agent, instead of placing it as subject, in order to obtain sentences that are clearer and easier to understand than their active counterparts.

and thus allow the sender to obtain a text which is at the same time allinclusive, clear and precise.

In a democratic society, rules must be imposed "gently" in order to avoid negative reactions, and they must in principle be applicable to everybody without discrimination. Furthermore, the rules have to be not only all-inclusive, but also clear and precise so that they can be understood and observed by the receivers. The use of the passive may help the sender (the legislator) to meet these requirements, and thus contribute to the successful establishing and enactment of rules regulating life in society. 


\subsubsection{Passive voice as a rhetorical strategy within the inter- active moves}

Having considered the passive voice as one of the general rhetorical strategies used in the French directive we will now turn to another important aspect of genre analysis, namely its suitability for interlingual contrastive text analysis. To this end we will compare the French and the German version of the directive investigated in this paper. Between communicative purpose and moves there is a relation of realization (moves realizing the communicative purpose), and a similar relation exists between moves and rhetorical strategies (rhetorical strategies formulating the moves). As the communicative purpose of a text may be found without regard to the national language, in which the analysed text is written, it is possible to formulate a more or less universal description suiting texts from several languages. As the two texts investigated here are equivalent to each other, they fulfil the same communicative purpose. The next step is to investigate, if (or to what extent) the communicative purpose is realized by the same move-structure in the texts from different languages. This is the case here. The German text shows the same linear move-structure as the French text investigated above, consisting also of the same types of moves. This means that we have here two texts from different languages with the same purpose and the same way of sequencing the realization of the purpose. What is interesting at this point is to investigate whether we find the same rhetorical strategies across the two languages within the same moves. If this is the case, we have good reasons to assume that within this genre, German passives (expressed by a construction with werden/sein + past participle) and French passives have similar functions. Such knowledge is especially important for legal translators. They need to know when to use similar linguistic means in the translation and when to look for other ways of realizing the same move.

As an example of such a contrastive study, we will now investigate the general distribution of the passive voice in move 3 (Establishing of rules) and the distribution within the interactive step-structure of this move in the German as well as in the French directive.

As mentioned above move 3 in the French version of the text has a total of 229 finite verb phrases, and 76 of these phrases (33\%) are in the passive form. Looking at the interactive move-structure (provisionary clauses vs. qualifications) of move 3 , we find at clause level an overall 
rhetorical strategy to phrase the provisions in the form of main clauses with constituent clauses and restrictive relative clauses connected to them and the qualifications in the form of adverbial or non-restrictive relative clauses (+ attributed restrictive relative clauses). This means that the distribution of passives in the interactive move-structure may be tentatively investigated as the distribution of passives between these two formal groups, although a screening of the clauses is necessary. ${ }^{7}$

The French text contains 70 finite verb phrases in main clauses. All of these clauses are in fact provisionary clauses. Only $9(13 \%)$ of these main clauses have their finite verb phrase in the passive voice. In contrast, there are 159 finite verb phrases in subordinate clauses. Of these 96 are found in subordinate clauses which actually represent qualifications. 42 of these 96 finite verb phrases (44\%) are passives, whereas the equivalent percentage of passives in subordinate clauses representing provisions is $24 / 63=40 \%$.

Not only are the vast majority of passives placed in subordinate clauses. The proportion of finite passive verb phrases compared to the number of finite active verb phrases is also very different between main and subordinate clauses (main clauses: $13 \%$ passive finite verb phrases, subordinate clauses: $44 \%$ and $40 \%$, respectively). These percentages show a strong tendency to use passive voice in subordinate clauses and also a strong tendency for active voice in connection with main clauses.

The German text has a total of 277 finite verb phrases. There are 94 finite verb phrases in main clauses (34\%), whereas 183 are in subordinate clauses $(66 \%)$. So the relation between main and subordinate clauses are similar to the results from the examination of the French text (main clauses: $70 / 229=31 \%$, subordinate clauses: 159/229 = 69\%), although the total number of finite verb phrases in the German text is considerably higher than in the French text. ${ }^{8}$ The total number of passives in move 3 in the German version is 75, resulting in a percen-

7 For the purposes of this article, we will not go deeper into the classification. The screening carried out in connection with this analysis has showed that in the vast majority of cases the tentative distribution of qualifications and provisionary clauses upon the formal categories listed above is correct. Further investigations will be necessary in order to refine the analysis and make it semantically more valid.

8 This aspect is not focused on in this paper. It is primarily due to differences in style between the two language versions. 
tage of $27 \%$ finite verb phrases in the passive voice. This overall percentage is a little lower than the result from the investigation of the French text above (33\%).

Concerning the interactive step-structure and the distribution of passives in the structure, the German text shows a total amount of 174 clauses functioning as provisions or parts of provisions (75 main clauses, 99 subordinate clauses). ${ }^{9} 44$ of these clauses $(44 / 174=25 \%$ ) have their finite verb phrase in the passive. So the percentage of passives in clauses connected to provisions is almost identical across the two language versions (French: 34/133 = $26 \%$ ). Both the French and the German text have 9 finite verb phrases in the passive voice in main clauses, but the higher number of main clauses in the German text means that the percentage of passives in main clauses is lower in German than in French (German: $10 \%$, French: $13 \%$ ). Looking at subordinate clauses connected to provisions, the number of passive finite verb phrases in these clauses is 25 , meaning that $40 \%$ of the finite verb phrases in these clauses are in the passive voice. The equivalent German figure is 35 of 99 clauses with passive finite verb phrases, meaning a percentage of $35 \%$. So what we have is a lower number of passives in the French text than in the German text, but at the same time the proportion of these constructions is higher in the French than in the German text.

Furthermore, the German text has 103 finite verb phrases in clauses functioning as qualifications or parts of qualifications. 84 of these $(84 / 103=81 \%)$ are verbs in subordinate clauses, whereas 19 are verbs

9 In connection with the aspect mentioned in note 8, we here have concrete example of the stylistic differences between the German and the French versions: The French version of the text does not contain any main clauses which are not provisions, whereas the German text has 20 such main clauses. Looking at the versions of article 7 of the directive reveals the difference:

Art. 7. Die Mitgliedstaaten sehen vor, dass die Verarbeitung personenbezogener Daten lediglich erfolgen darf, wenn eine der folgenden Voraussetzungen erfüllt ist:

a) Die betroffene Person hat ohne jeden Zweifel ihre Einwilligung gegeben; ...

Art. 7. Les Etats membres prévoient que le traitement de donnés à caractère personnel ne peut être effectué que si:

a) la personne concernée a donné son consentement; ou ...

Where the French version is phrased as a main clause with adverbial clauses containing the conditions, the German version phrases not only the central part of the sentence, but also the conditions as main clauses. What we have here are reflections of textual traditions within the two different national legal systems. 
in main clauses (see note 2). Of these finite verb phrases, 31 are in the passive voice $(31 / 104,30 \%)$. All tokens of finite verb phrases in the passive voice in qualifications are in subordinate clauses. We have, thus, a slightly higher number of qualifications in the German than in the French version (German: 103, French: 96), but a higher proportion of the qualifications in French (German: 103/277 $=37 \%$, French: $96 / 229=42 \%$ ). The number of passive verb phrases connected to this step is higher in the French than in the German text (German: 31, French: 42), and the percentual difference is higher (German: $30 \%$, French: $44 \%$ ). Even if we exclude the qualifications expressed in main clauses from the German figures, we still have a considerable difference between the two versions (German: $37 \%$, French: $44 \%$ ). So, concerning the proportion of the passive, we have the same picture as when looking at main as well as subordinate clauses connected to provisions: the proportion of the passive is higher in the French than in the German text.

Let us end this exemplification by stating that the comparison of the step-structure and the distribution of clauses and of finite verb phrases in the passive voice across languages have shown that the major difference between the two versions lies in the number of clauses used (German: 277, French: 229) and the relation between provisions and qualifications (German: $37 \%$ qualifications, French: $42 \%$ qualifications). Concerning the passive finite verb phrases, we see a tendency to use more passive voice when formulating the steps in the French than in the German version of the text. We saw the highest difference in percentage when comparing clauses connected to qualifications (German: $37 \%$, French: $44 \%$ ), whereas the overall distribution of passive voice for clauses connected to provisions is equal across the two language versions, and there is a difference between the relevant subordinate clauses (German: $35 \%$, French: $40 \%$ ). This means that the difference in the number of clauses between the two language versions may now be described in more detail:

1. The additional clauses in the German text are primarily provisions or clauses connected to provisions

2. The additional subordinate clauses are primarily provisions.

3 . The additional main clauses are primarily qualifications.

4. The additional subordinate clauses show a tendency to have active 
finite verb phrases (as the proportion of the passive is lower in the German than in the French text.

We have, thus, proved the applicability of genre analysis for comparisons of the use of the syntactic feature "passive voice" across languages.

\section{Applications of genre analysis}

As we have seen, modern genre analysis is suitable for various practical linguistic purposes, when describing legal texts and searching for functional explanations for characteristic features of these texts. In this last section, we shall mention some of the further applications of genre analyses of legal texts like the one demonstrated here:

\section{a) Language reform}

Results of genre analysis may be especially relevant in the reform of the writing of legislation and of other public documents. On the basis of descriptions and explanations from genre analysis, it is possible to argue in a substantive way about how far the conventionally used rhetorical strategies serve a specific legal purpose and to what extent they are just reminiscences of the past. In order to consider this question, it is first of all necessary to understand the rationale of the genre. After this, reforms may be proposed which are loyal to this purpose. Such propositions will undoubtedly have a better chance for success in the specialist community than the radical reforms suggested by the plain language movements. For genre analysis takes its point of departure inside the specialist community and does not intend to neutralise the integrity of legislative writing.

\section{b) Legal language courses for translators}

In legal language courses for translators there has been a move from focusing on the content and the meaning of the texts and the terms (i.e. the law) towards now including also the linguistic conventions and the extra-linguistic characteristics. Genre analysis has played and may still play an important part in this development. At the same time the focus has shifted from the particular texts used for translation exercises to genre analysis and generic similarities between texts within the particular genres: legislative texts, contracts, judgements. Using this methodology, the translation trainees get a better possibility to understand the 
rationale behind the texts, and achieve awareness of the specialist language.

\section{c) Cooperation between lawyers and linguists}

If we look at the literature on legal texts, it seems that lawyers have often adopted a purely legal point of view and linguists a purely linguistic point of view, for example focusing on formal grammar. Genre analysis has however the potential of creating a common ground, where not only linguistic features are taken into account but also the legal context. In this way, it opens for co-operation between the two specialist communities. And it may be added, that in fact, as pointed out by Bhatia, the genre analyst should always:

"double [check] his findings against reactions from a specialist informant $[. .$.$] . The specialist reaction confirms his findings, brings val-$ idity to his insights and adds psychological reality to his analysis. It is an important aspect of genre analysis, if one wishes to bring in relevant explanation rather than mere description in one's analysis."

(Bhatia 1993:34).

Such co-operation will most certainly prove very fruitful to both parties.

\section{References}

Bhatia Vijay K. (1993). Analysing Genre: Language Use in Professional Settings. London: Longman.

Bhatia, Vijay K. (1996). Methodological Issues in Genre Analysis. In Hermes 16. 3960.

Bhatia, Vijay \& Engberg, Jan \& Frandsen, Finn \& Johansen, Winni \& Nielsen, Martin (1997). On Vijay K. Bhatia: Analysing Genre: Language Use in Professional Settings, 1993. In Hermes 19. 207-239.

Cornu, Gérard (1990). Linguistique juridique. Paris: Montchrestien.

Nølke, Henning (1995). Utterance Focus. Elements of a Modular Theory. In Copenhagen Studies in Language 18. 75-114.

Prince, Ellen (1981). Toward a Taxonomy of Given-New Information. In Cole P. (Ed.). Radical Pragmatics. New York: Academic Press. 223-255.

Rasmussen, Kirsten W. (1996). La motivation du passif. Etude de corpus. In Scolia 7. 95-116.

Swales J. M. (1990). Genre Analysis. English in Academic and Research Settings. Cambridge: Cambridge University Press. 